\title{
THE PERSIUS GROUP OF THANAOS (LEPIDOPTERA, HESPERIIDAE)
}

\author{
By William T. M. Forbes, \\ Cornell University, Ithaca, New York
}

This group has been a standing problem for many years. On the one hand, the superficial and genitalic differences of the adults are so small that the late Dr. Skinner and various other workers were convinced that there was only a single variable species. On the other hand, the earliest rearings showed that there were two widely divergent foodplants (columbine and willow or poplar), associated with visible differences in appearance of the butterflies; and later work has added Baptisia as a third,--each belonging to a different and widely separated family of plants. This for the East; in Arizona we must add afranius Lintner, and California has a complex that only local rearing can straighten out. In this paper I am taking the persius group in its strictest sense, comprising only the forms with genitalia of identical plan: socii rather long, equal in size and spike-like (one more curved than the other) ; left valve with three strong lobes, the middle one longitudinal in general direction, right valve two-lobed, with a short tooth on the upper outer angle of the lower lobe, to represent the middle lobe of the left side. This definition will include the three eastern types, afranius, and California specimens identical in structure with persius and afranius, but will exclude the Californian lilius and callidus, also pernigra if rightly identified at the National Museum. T. avinoffi of Alaska probably is also included, but has not been examined structurally.

I use the name Thanaos for familiarity. Erynnis may be defended on the basis of the code, but has no effective use in this sense, and substantial use in another subfamily; so should be excluded by a conservanda ruling if the code continues to function.

The present paper is drawn up from the eastern point of 
view. West of the Mississippi river there may be additional complications. There is a divergent looking form from Omaha, Nebraska (two specimens at hand) ; afranius shows some sign of complexity, that should be cleared up by more extensive rearing, and of the California material only that which could be placed in more eastern species has been analyzed. Lucilius and the Baptisia species appear to be absent from California, but there is a black species with the structure of afranius to complicate matters. True persius is more common in California than in the east, but has been generally mistaken there for afraniuis.

The crux of the confusion has been the current mistaking of the Baptisia species for persius, which has generally gone unrecognized, or been determined erroneously as afranius, -and back of this confusion is the fact that true persius is relatively scarce from the east in collections, and perhaps the slight miscoloring of Scudder's figure. Speaking generally Scudder, Holland and the U. S. National Museum had persius correctly identified, while Skinner, Lindsey and the Barnes collection had the Baptisia species standing as persius, with possibly a few scattered eastern specimens of true persius, while the main series of persius were western specimens and stood as afranius. The true persius has excellent genitalic characters, and east of the Rocky Mountains may be distinguished by its coating of long scattered white hairs on the disc of the forewing. In Arizona all the group become heavily covered with white, but in California I believe persius again is the only one with the white hairs.

\section{Thanaos persius Scudder}

1862. Nisoniades persius Scudder, Proc. Essex Inst. iii 170.

1870. Nisoniades persius Scudder \& Burgess, Proc. Boston Soc. Nat. Hist. xiii, 286, fig. 1 (genitalia).

1889. Thanaos persius Scudder, Butt. E. N. A. ii, 14681476, pl. ix, fig. 1, xxxvi, fig. 1-3, etc. (colored figure perhaps contaminated with Baptisia species).

1872. Nisoniades persius Lintner, 23rd Rept. N. Y. State Cab. Nat. Hist. 165 (note), pl. vii, figs. 3, 4 (Ent. Cont. p. 33). 
1898. Thanaos persius Holland, Butt. Book pl. xlviii, fig. 1, (a California specimen).

1921. Thanaos persius, race afranius Lindsey (approximately) Univ. Ia. Stud. ix (4), 52.1

1927. Erynnis persius afranius Comstock, Butt. Calif. 212 (in part), pl. lix, fig. 2 (not fig. 3).

1931. Erynnis afranius Lindsey, Bell \& Williams, Denison Univ. Bull., Jour. Sci. Lab. xxvi, 62 (in part) (not Nisoniades afranius Lintner).

There is further bibliography in Scudd. '89, Lindsey '21 and '31, and Skinner Syn. Cat. No. Am. Rhopalocera, but the latter three must be used with caution on account of the confusion of species.

It would appear that Scudder had a pretty clear idea of this species, as shown by the type (whose genitalia I figure, fig. 5), the Scudder and Burgess figure of the genitalia, and the biological data and foodplants. But his figure shows too much brown, and may possibly have been contaminated by the Baptisia species. Holland figures it correctly from a California specimen ${ }^{2}$, and the main series in the National Museum (representing Dyar's determination) is correct and pure; but Skinner failed to recognize it, most of his series being of the Baptisia species, which is far commoner in the east; and several later workers have followed his misidentification, apparently viewing the occasional eastern specimen as aberrant, and putting the western material in afranius.

Superficially persius can be instantly recognized in the east, and I believe in the Northwest and California, by the abundant hair on the base and disc of the fore wing, some of which is white, and the general smooth appearance, the pale spot over the end of the cell being gray when distinct. In Arizona the other species show the same pale hair, but can be distinguished by the genitalia. Afranius also differs as a rule in the paler outer margin of the fore wing, due to a large percent of white scales; on which the wedge-like

1This determination judged by the arrangement of the Barnes collection as deposited in the U. S. National Museum.

2The apparent transparent cell-spots are pin-holes. 
black postmedial spots, and less defined submarginal and marginal ones contrast strongly. The pale fringe, emphasized by Lindsey, occurs in specimens of both types of genitalia, and is probably a dry climate modification of all the species.

The chief characters are: left valve with middle lobe much widened, separated from the upper lobe by less than its width, with a heavy keel on its inner face, extending about half way to the tip (present in a single aberrant or hybrid specimen of afranius) ; upper lobe with spinulation limited to its apical part; right valve with upper lobe massive, separated from lower by a narrow chink, its tip recurved into a massive, heavily spinulated hook, which invariably folds back on itself in the mounted valve, its outer lower edge not toothed, more or less lobed and hairy at the middle; the whole larger than in any afranius or lucilius, or most baptisix, being over $0.8 \mathrm{~mm}$. long with few exceptions, and over $0.62(5 / 8) \mathrm{mm}$. wide in all specimens seen. Lower lobe short and heavy, less than twice as long as upper lobe, its tip ending in a more or less distinct rounded thickening on inner side, and wholly without teeth. The whole structure, including the tegumen, is more massive than the other species. The broad middle lobe on the right side can be seen without dissection, but is set on obliquely and often seems narrower than it really is.

I have specimens before me from Bristol (fig. 1) and Johnston, R. I., New Haven, Conn., Crosby and Yapyank, N. Y., Eagle, Ala., and numerous western specimens, mostly from Col., Wyo., Alta. and Cal. The latter are generally mixed with afranius, but the massive genitalia will distinguish them; in fact some California specimens are more massive than the eastern ones. I have only seen spring dates from the east, though it flies in July in the Rocky Mountains, so I believe it is single brooded, in the spring where the climate permits.

In the remaining species the middle lobe of the right valve is slender, with a wide space between it and the upper; and its inner keel is weak and stops practically at its base; the upper lobe shows some tendency for the hair to extend down in a line to near the base of the middle lobe 
(especially in afranius); the upper lobe of the right valve is smaller, and its lower outer edge is not lobed and is more or less distinctly toothed; the lower lobe is long and slender and toothed at the tip (the teeth weak or occasionally ab-
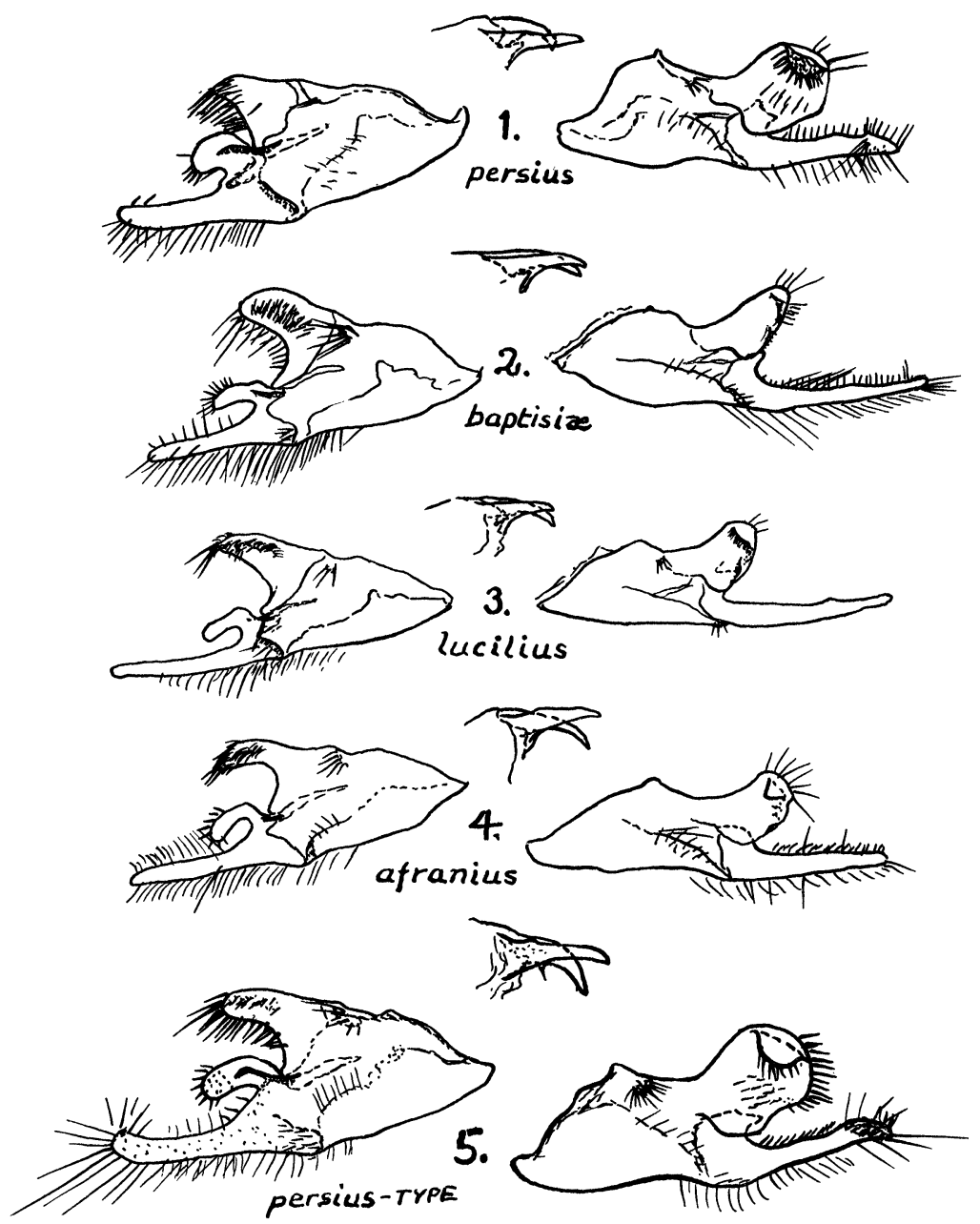

Fig. 1. Each figure shows the left valve on left, tegumen in side view in the center, and right valve at right. 1, T. persius, Bristol, R. I. 2, T. baptisix, type, Woods Hole, Mass.; 3, T. lucilius, Ithaca, N. Y.; 4, T. afranius, Ariz.; 5, T. persius, type, Mass. 
sent in afranius). The hair on the fore wing is all dark or with two or three scattered white hairs in eastern specimens, and seems less dense as a whole; in Arizona it becomes more visible, but seems less than on persius from the same neighborhoods. In afranius, where there is more hair, the white scaling is also increased in even greater proportion.

\section{Thanaos afranius Lintner}

1878. Nisoniades afranius Lintner, 30th Rept. N. Y. Mus. Nat. Hist. 175.

1898. Thanaos afranius Holland, Butt. Book, pl. xlv fig. 5. 1921. Thanaos persius, race afranius Lindsey, Univ. Ia. Stud. ix (4), 52 (in part).

1927. Erynnis afranius Lindsey, Denison Univ. Bull. Jour. Sci. Lab. xxii, 109 (larva on lupine and discussion).

1927. Erynnis persius afranius Comstock, Butt. Calif. 212 (in part), pl. lix, fig. 3 ( ?, not fig. 2).

1931. Erynnis afranius Lindsey, Bell and Williams, Denison Univ. Bull., Jour. Sci. Lab. xxvi. 62 (in part).

This species is intermediate between the preceding and following, but may usually be distinguished from both by its pale gray outer part of the fore wing, with contrasting black markings (as seen by naked eye). In California there is a form with identical structure, however, that is mostly blackish, and should be looked into biologically.

Male genitalia intermediate between persius and the other two species, and more variable than either (suggesting possible origin by hybridization). Hair of upper left lobe usually in two distinct rows, both long, and converging to the upper notch, the upper row very dense in the area corresponding to the smaller hair patch of persius; sometimes the two rows confused by the presence of considerable hair in the intervening area ; right valve more distinctive, similar to lucilius, but with the chitinous teeth weak, both on the edge of upper and tip of lower lobes, occasionally not visible on one or both; tip of upper lobe intermediate, almost invariably turning under in a mounted slide as in persius, but relatively small. Genitalia as a whole much 
smaller than in persius, there being no overlap in size. The right upper lobe seems to vary a good deal in shape, with very little variation in size (unlike lucilius, whose average size is about the same).

Most of the specimens I have seen come from Arizona; there is one before me from Colorado (Oslar).

Thanaos lucilius Scudder and Burgess

1870. Nisoniades lucilius Scudder and Burgess, Proc. Boston Soc. Nat. Hist., xiii, 287, fig. 2 (male genitalia).

1872. Nisoniades lucilius Lintner, 23rd Rept. N. Y. State Lab. Nat. Hist. 162, pl. vii, figs. 1, 2 (Ent. Cont. p. 31).

1873. Nisoniades lucilius 24th Rept. N. Y. State Lab. Nat. Hist., 162, 164, 167 etc. (Larva on Aquilegia).

1889. Thanaos lucilius Scudder, Butt. E. N. A. ii, 14581467, pl. ix, fig. 4, xxxvi, figs. 4-6, etc.

1898. Thanaos lucilius Holland, Butt. Book, pl. xlviii, fig. 10.

1921. Thanaos persius, race lucilius Lindsey, Univ. Ia. Stud. ix (4) 52, (pl. ii, fig. 5; male genitalia probably of this, as persius).

1931. Erynnis lucilius Lindsey, Bell and Williams, Denison Univ. Bull. Jour. Sci. Lab. xxvi, 62 (pl. xiv. reprinted from preceding).

Bibliography under this name is generally correct, the foodplant serving to tie it down.

Genitalia essentially as in baptisiæe, but apparently on the average with the upper lobe of the right valve broader in proportion. Size much more variable than shape (unlike afranius) but generally a little smaller than baptisiæ, about in proportion to the size of the butterfly.

Superficially lucilius has a more purplish tint, the paler areas, especially the one beyond the cell, having even a rosy iridescence in a favorable light (mentioned by Lintner). The average size is smaller, generally under $30 \mathrm{~mm}$. expanse. The blackish markings on the fore wing are apt to be a little narrower; for instance, the ante- and postmedial spots in the submedian area are generally shorter than their 
distance apart. Scudder separates lucilius from persius as having "a large, somewhat distinct patch, paler than the ground color, between the cellular and subcostal vitreous spots of the fore wings." This character generally holds against true persius, but is shared by baptisix. There is very little white hair, if any, in eastern specimens.

Lucilius has been frequently reared, always from Columbine. It has two or three broods. I have examined unmistakeable specimens from as far as Nebraska, but its western extent must be verified by larval determinations. If there is a western strain it has been mixed with afranius.

Thanaos baptisiæ new species

1889. 'Not Thanaos persius' Scudder, Butt. E. N. A. ii1473 (larva on Lespedeza, perhaps another species).

1921. Thanaos persius Lindsey, Univ. Ia. Stud. ix (4), 52 (in part, including generalities and perhaps figure of genitalia).

1931. Erynnis persius Lindsey, Bell and Williams, Denison Univ. Bull., Jour. Sci. Lab. xxvi, 62 (in part, perhaps figure of genitalia, but not discussion of larva).

Thanaos persius of most eastern collections, but not of Scudder).

Similar to T. lucilius, so close that a comparative description is in order. Average size slightly larger (mostly over $30 \mathrm{~mm}$.). Ground a more yellow brown; in direct light a dull umber, in favorable light showing just a trace of the purple iridescence of lucilius. Pale areas produced mainly by a luteous ground (while in lucilius the ground is hardly paler than the dark areas, but there is a higher percent of white scales), but with some white scaling, especially toward costa. Iridescence somewhat less difficult than on dark areas, brassy, in some lights with a distinct greensh tint. In the type, a fully marked specimen, the pale areas are spots antemedially, medially and postmedially in fold, separated by wider dark bars, very faint flecks in cell, fairly complete post medial and subterminal fasciæ (including the submedian spots already mentioned), and much smaller 
and paler preterminal spots; all these essentially as in lucilius, except as noted in color. Hind wing and under side like lucilius. Dark males show a blurring and lack of contrast of the paler and darker areas, both of which are umber brown. Rubbed specimens tend to develop an iridescence like that of lucilius, but lose the white scaling more completely. Female essentially like male (except lack of costal fold) but as usual paler, more mottled looking, and with a tendency for the paler areas to increase on the outer half of the wing.

Male genitalia (fig. 2) substantially identical with $T$. lucilius. Left valve with upper lobe widely divergent from middle lobe, the spinulation on inner surface forming a band extending about to base of lobe; middle lobe of even width, sharply curved ventrad, with a rudimentary keel on inner face running into its base. Lower lobe slender and somewhat tapering, separated by its width from middle lobe Tubercle at middle of costa with 6 or 8 hairs. Right valve with upper lobe tapering toward tip, not densely spined, the tip not recurved, but bearing on its inner face a sharp raised ridge which is clothed with very fine spinules and granules. A similar ridge along or very close to its outer edge, more granulose than spinulose, and connected with the first by a few granules on the face of the lobe. Middle lobe represented by a small sharp tooth overlying face of upper lobe; lower lobe slender, twice as long as upper lobe, widely divergent and tapering, with distinct terminal teeth. Uncus as usual; the left spine nearly straight and right spine sharply curved, more pointed than in persius, but substantially as in lucilius.

Type and paratypes from Woods Hole, Mass., July, Cornell Univ. type no. 1391. Allotype from Decatur, Ill., July, reared from Baptisia (in U. S. National Museum from Barnes coll.). The types were taken in close association with Baptisia tinctoria, though the females were not seen actually ovipositing. They hovered most persistently over tiny dwarf plants in the paths. I have also seen specimens that seem to be this from other points in New England, N. Car., Pa., Nebr. and Fla., but prefer not to make them types as none were associated with food plants. A single speci- 
men from Arizona in coll. Townes has the same size and genitalia, and some of the brassy iridescence, but is much overlaid with white. It is certainly not persius or afranius. There are two broods, in May and July, but spring specimens seem rare.

\section{Thanaos avinoffi Holland}

1930. Thanaos avinoffi Holland, Ann. Carn. Mus. xix (3), 156.

1931. Thanaos avinoffi Holland, Butt. Book (Revised Ed.), 352, pl. li, figs. 28, 29.

1931. Erynnis avinoffi Lindsey, Bell and Williams, Denison Univ. Bull., Jour. Sci. Labs. xxvi, 62.

I have examined this only superficially but believe it a race of persius, whose food, willow, is a common species in the far north. A superficial examination of T. propertuis var. borealis Cary, from the Canadian Northwest, inclines me to believe it is also a persius-strain, and transitional to avinoffi. 

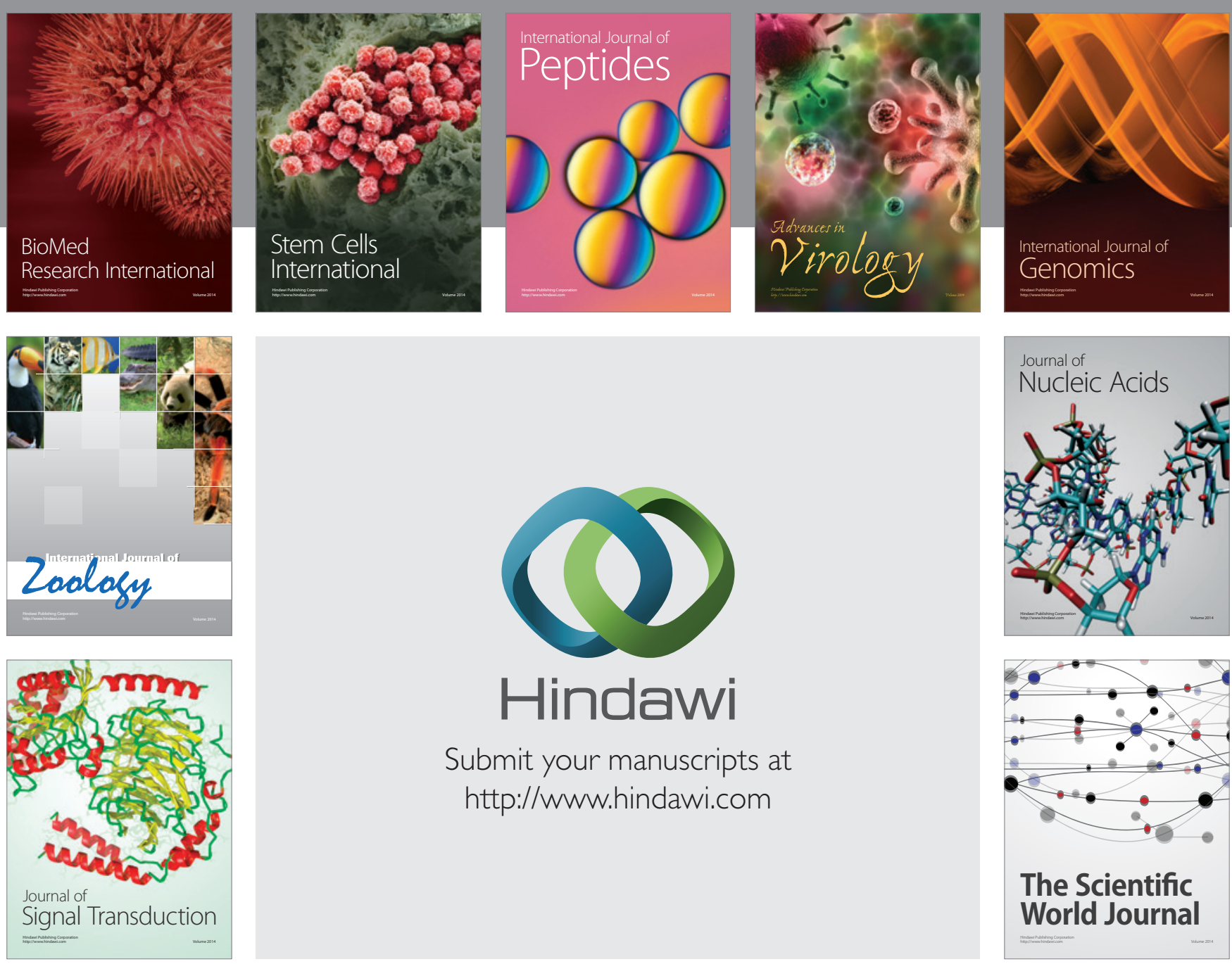

Submit your manuscripts at

http://www.hindawi.com
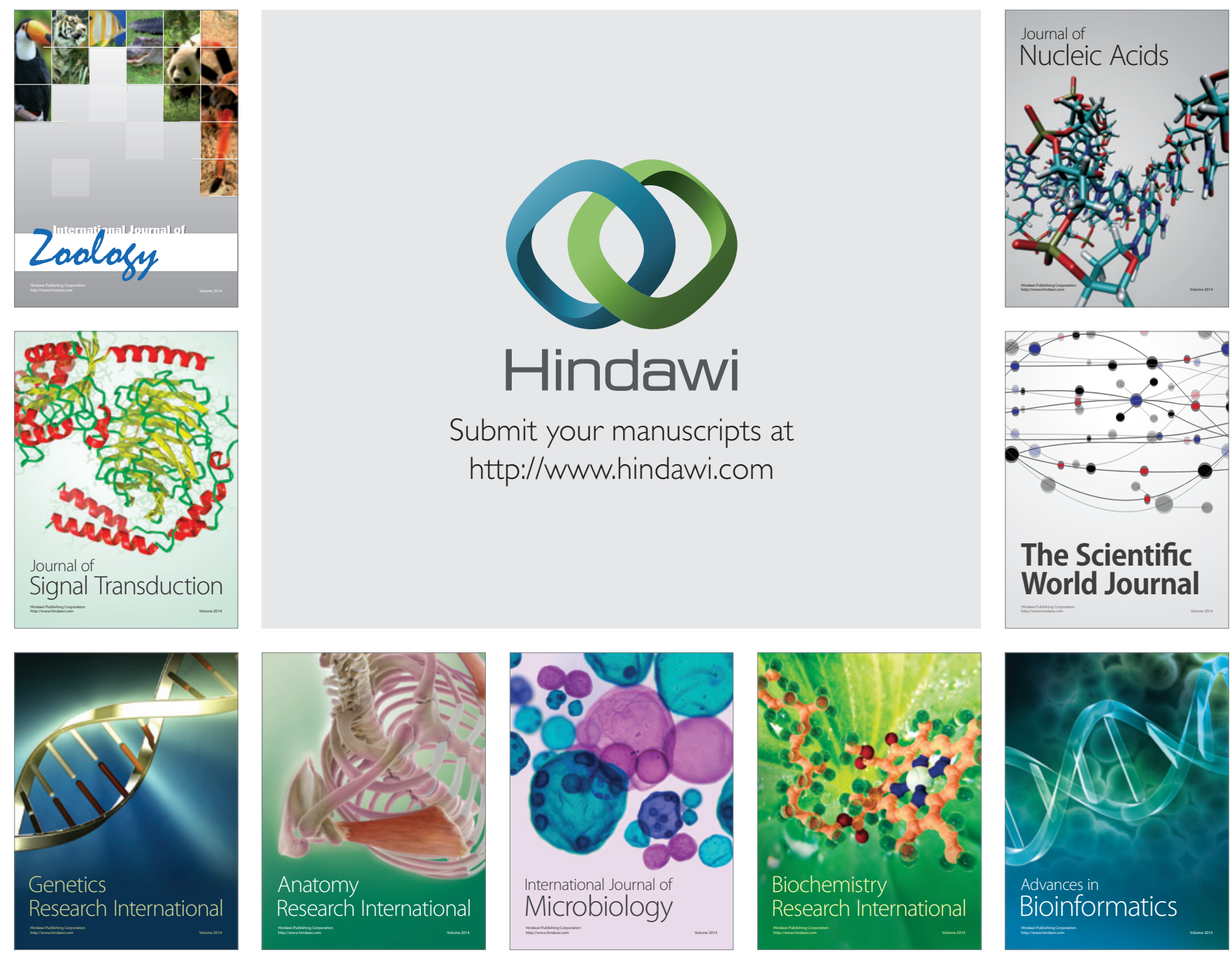

The Scientific World Journal
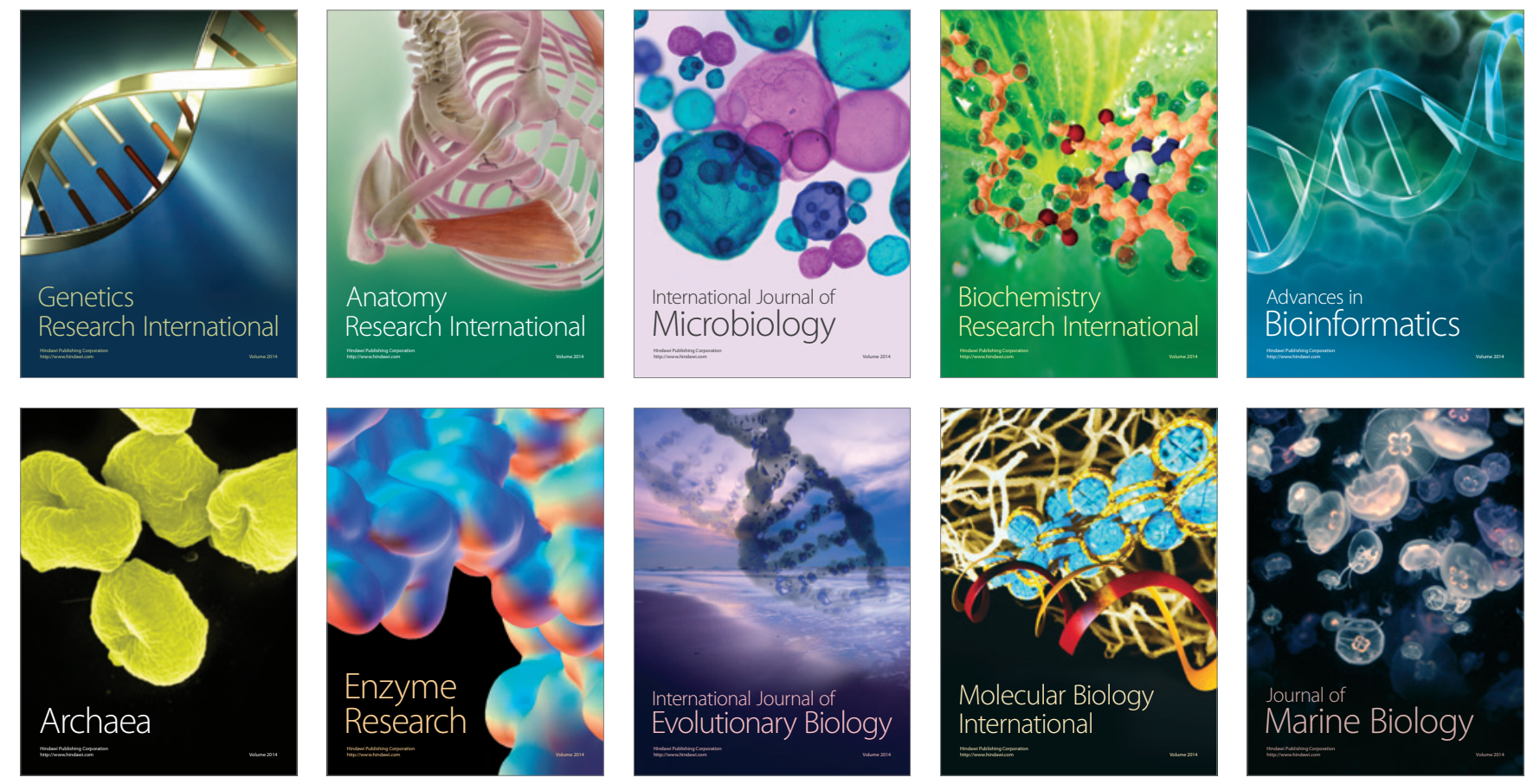